\title{
Comparative Study of Consistency Behavior and Shear Strength of Clayey Soils of Rajshahi District, Bangladesh
}

\author{
Ankur Nandy, Noosrat Rashid, Md. Ashikuzzaman*, Syed Abdul Mofiz \\ Department of Civil Engineering, Rajshahi University of Engineering \& Technology, Rajshahi, Bangladesh \\ Email address: \\ ankur.nandy04@gmail.com (A. Nandy),noosrat.pushpo@gmail.com (N. Rashid), ashik.amjr120116@gmail.com (Md. Ashikuzzaman), \\ samofiz@yahoo.com (S. A. Mofiz) \\ ${ }^{*}$ Corresponding author
}

\section{To cite this article:}

Ankur Nandy, Noosrat Rashid, Md. Ashikuzzaman, Syed Abdul Mofiz. Comparative Study of Consistency Behavior and Shear Strength of Clayey Soils of Rajshahi District, Bangladesh. Journal of Civil, Construction and Environmental Engineering. Vol. 4, No. 1, 2019 , pp. $28-34$. doi: $10.11648 /$ j.jccee.20190401.13

Received: February 19, 2019; Accepted: March 26, 2019; Published: May 11, 2019

\begin{abstract}
This paper aims at introducing the Fall Cone Test (FCT) to obtain the shear strength of clayey soils and reveals its applicability by comparing the results obtained from that of Unconfined Compression Test (UCT). Furthermore, the liquid and plastic limit obtained from Casagrande method also compared with that obtained from FCT. For these, soils were collected from Godagari, Tanore, and Nauhata from Rajshahi District (RD). At first, Hydrometer analysis was performed in each soil to know the physical properties. Then Atterberg Limit test was carried out by considering Casagrande Method. After that UCT was shown in each land to find the shear strength of the clay soils. Lastly, FCT was conducted to find out the shear strength, LL and PL. FCT shows a lower amount of liquid and plastic limit than the values measured in the Casagrande Method except plastic limit for Tanore for FCT whereas Godagari shows the higher value of shear strength considering FCT. This research can be concluded with further research should be conducted to ensure its accuracy. On the other hand, it can be drawn which soil have more consistency and shear strength considering others.
\end{abstract}

Keywords: Fall Cone Test, Unconfined Compression Test, Casagrande Method, Consistency Behavior, Shear Strength

\section{Introduction}

Clay is a type of soil material which carries the fickle quantity of water entrapped in the mineral structure. Due to ample void ratio, clay can be classified as the fine-grained natural rock as well. Clays show plasticity because of their moisture content and convert into hard, brittle and nonplastic materials when clays undergo drying or firing. Silts and clays can be separated by the soils' Atterberg limits depending on the plasticity properties of the soil. Based on the gradation of ISO 14688, particles smaller than two $\mu \mathrm{m}$ are classified as clay particles, and silt particles are more substantial than that. The term Shear strength indicates the sustainability of shear stress of the soil. The shear resistance of land is a result of friction and interlocking of particles, and possibly cementation or bonding at particle contacts.

Clay is a naturalistic material made generally of finegrained minerals representing plasticity through the different extent of water content. Clay can be stiffed at the time of experiencing drying and firing processes. Clay deposits mostly formed of clay minerals which impart resilience and harden when burned or dried and the variable amount of water trapped in the mineral structure by polar attraction. Clay deposits are also comprised of some organic materials which do not have plastic properties. The formation of clay mineral is a long term process which is generally occurred by the gradual chemical weathering of rocks usually silicatebearing by the low concentration of carbonic acid and other diluted solvents. These solvents generally acidic migrate through the weathering rock after leaching through weathered upper layers. Because of hydrothermal activities, different clay minerals are also formed in that weathering action. Clay deposits typically associated with deficient energy depositional environments such as large lake and marine sediments. Primary clays also known as Kaolin's are located at the site of formation. Secondary clay deposits have moved by erosion and water from their prime location.

Shear strength of a soil is generally preferred as the point 
at which significant plastic deformation or yielding occurs under the regular application of shear stress. It is also known as the highest concentration point of the soil in that case. The shear strength of land is based on the shearing as a reference model. One of the two theories is Tresca theory which is essential for short-term loading of soil and for long-term filling of earth, Mohr-Coulomb theory associated with the principle of effective stress is necessary. Shear strength measured by Tresca theory is commonly known as the undrained strength or the total stress condition while the designation is the drained strength or the current stress condition determined by the other argument. These traditional approaches may be replaced by two theories, such as- critical state theory and steady state theory in modern soil mechanics. For both undrained and drained terms, either of the two approaches can be applied. The methods are also crucial for partial drainage. The value of $\varphi$ usually varies from $37^{\circ}-38^{\circ}$ approximately with a plasticity index of about 10 , to around $25^{\circ}$ or less with a plasticity index of about 100 provided by Kenney (1959).

This paper emphasises on the comparison of Liquid Limit, and Plastic Limit obtained from two different methods, i.e., Fall Cone Test and Casagrande Method and also compares the shear strength of the tested clay soils from unconfined compression strength and the empirical formula of Fall Cone Test. On the other hand, physical and geotechnical properties measured of the clayey soils in the laboratory.

\section{Literature Review}

From the studies of few last decades, it can be shown that the determination of atterberg limits using fall cone test method has become well known to the Geotechnical related researchers [1-12]. Several researchers have already tried to find out the difference or the comparison of Casagrande and fall cone penetrometer method in the region-based study.

Christaras [13] examined to investigate liquid limit using two well-established methods namely Casagrande and fall cone penetrometer method in a Greek island in the eastern Mediterranean Sea named Crete in Greece. He noticed that the two ways gave almost the same results. He also investigated that liquid limit, plasticity index, and activity are correlated in the similarity of the Casagrande and fall cone penetrometer method whereas changes of specific gravity do not affect. Besides, in this research only liquid limit has been taken as consideration except for plastic limit. Spagnoli [14] saw that the code of practice is entirely different during any construction in accordance with the owners and the contractors for this he tested 50 samples consisted of kaolinite and illitic pure clayey soil considering BS (Cone Penetrometer Method) and DIN, German (Casagrande cup) and finally concluded with the similarity between the two methods. Hrubesova et al., [15] tried to determine the comparison between Casagrande Method and the Cone penetrometer method on two types of soils, i.e., intermediate plasticity (loam) and considering high resilience (sodium bentonite). Due to having problems in the measurement, and also in the blow rates fall cone is regarded for the measure of the consistency of the soils as more accurate method rather than Casagrande Cup Method. Another problem also arose in silty or sandy soils using Casagrande method [16]. Several researchers have also introduced and noticed different apex angles with varying weights of the cones using in the fall cone method [8, 17]. Recently, Sariosseiri and Muunthan [18] were investigated using two cones having different weights gave significantly same results in the determination of the plastic limit. Adhesion property also had been introduced exposing the influence of roughness of the surface on fall cone [17], and this effect had more cabalistic with a $60^{\circ}$ apex angle [8]. The work is done [19-20] displayed taking a penetration of about 2 to $2.2 \mathrm{~mm}$, the required plastic limit can be determined using a correlation plot of the penetration depth concerning the liquidity index obtained in the cone penetrometer test. A recently published technical report [21] introduced a device which can determine the consistency of the clay soils automatically based on a calibration of a term of $\mathrm{K}$ factor, depth of the penetration, and cone weight.

\section{Site Selection}

This experimental work was carried out at the geotechnical laboratory of Civil Engineering Department of Rajshahi University Of Engineering and Technology. For this experiment, the soils were collected from three well-known places which have already been in the clay soil zone of BARIND track of greater Rajshahi district. These three sites are Godagari, Tanore, and Nauhata. Soil samples were collected as a disturbed sample of more or less than two feet depth from the ground surface. These soil samples are of clay type soil by doing finger squish. These soil are very much hard in nature.

\section{Research Methodology}

Grain Size Distribution, Atterberg Limit Test, Unconfined Compression Test, and Fall Cone Test performed for Godagari soil, Tanore soil and Nauhata soil in this research. The test results and the discussion of these results described below.

\section{Results and Discussion}

\subsection{Particle Size Distribution}

In imitation of USDA soil classification, it was figured out the approximate percentages of soils. The particle size distribution curve was plotted considering Godagari soil in figure 1 and from figure 1 , it is easily displayed that $22 \%$ of sand, $30 \%$ of silt and $48 \%$ of clay, and the curve was plotted considering Tanore soil in figure 2 and from figure 2 , it is easily displayed that $26 \%$ of sand, $34 \%$ of silt and $40 \%$ of clay and also curve was plotted considering Nauhata soil in figure 3 and from figure 3 , it is easily displayed that $23 \%$ of sand, $39 \%$ of silt and $38 \%$ of clay. 


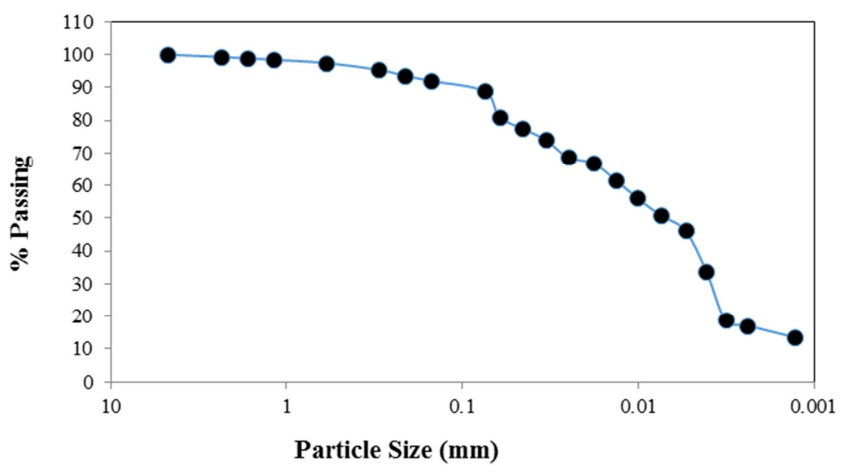

Figure 1. Particle Size Distribution Curve for Godagari Soil.

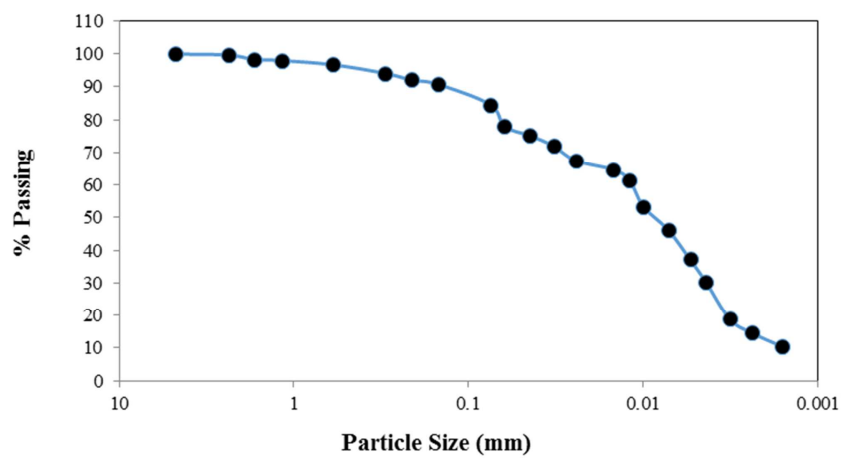

Figure 2. Particle Size Distribution Curve for Tanore Soil.

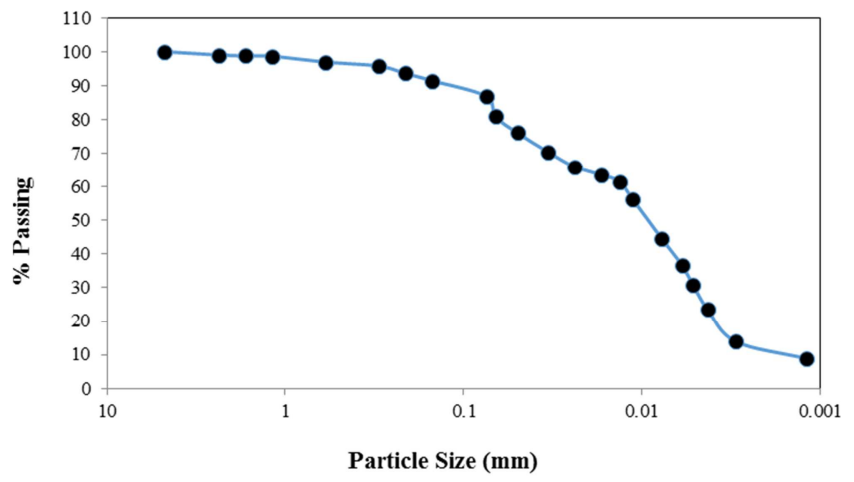

Figure 3. Particle Size Distribution Curve for Nauhata Soil.

\subsection{Casagrande Method}

The liquid limit and plastic limit in total considered as the atterberg limit test. Here, these are evaluated following the ASTM code of practice. On the other hand, Plasticity Index was also assessed to characterise the soil consistency were displayed here.

\subsubsection{Liquid Limit (LL)}

The water content, in per cent, at which soils behave like a liquid but still had some shear strength is called liquid limit of that soil. It is determined considering water content (w) by Casagrande Method in the laboratory at the exact 25 blows in the semi-log graph. In this research, ASTM D-4318 was adopted to evaluate the liquid limit. The results were plotted in a semi-log graph paper and were depicted in Figures 4, 5, and 6 for Godagari, Tanore, and Nauhata respectively. From the Figures 4, 5 and 6, the LL was obtained taking no. Of blows of 25. The LL limit of Godagri, Tanore, and Nauhata are $36.14 \%, 30.08 \%$, and $28.96 \%$ respectively.

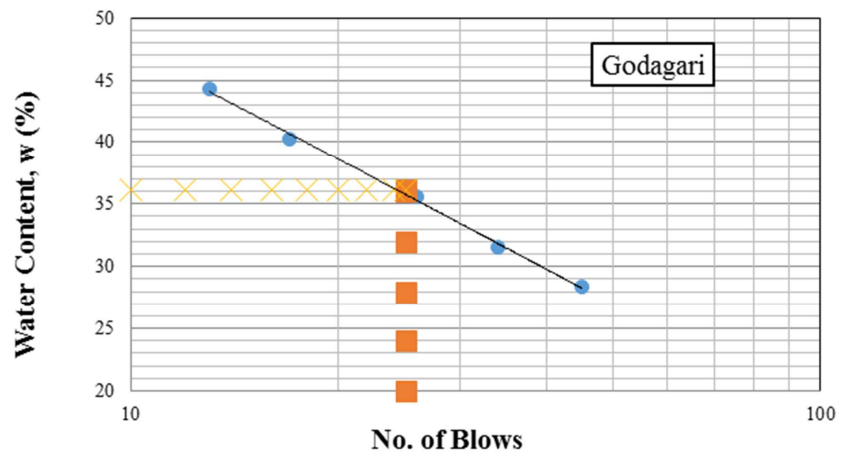

Figure 4. Graph for liquid limit determination by Casagrande Method (Godagari Soil).

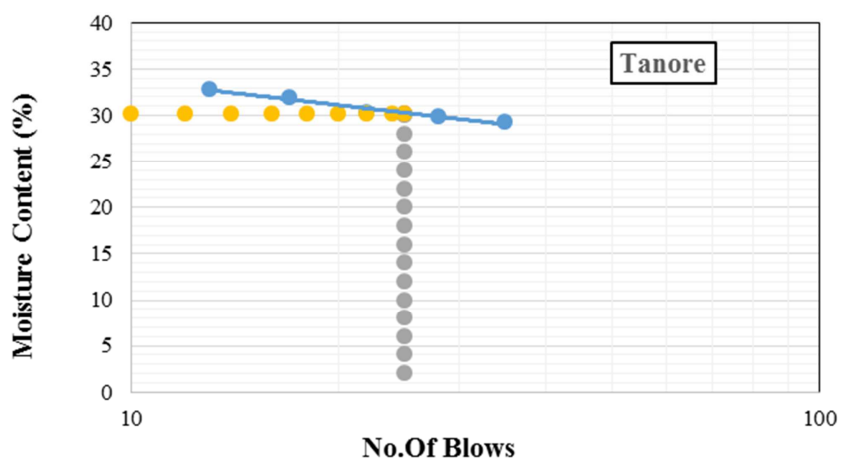

Figure 5. Graph for liquid limit determination by Casagrande Method (Tanore Soil).

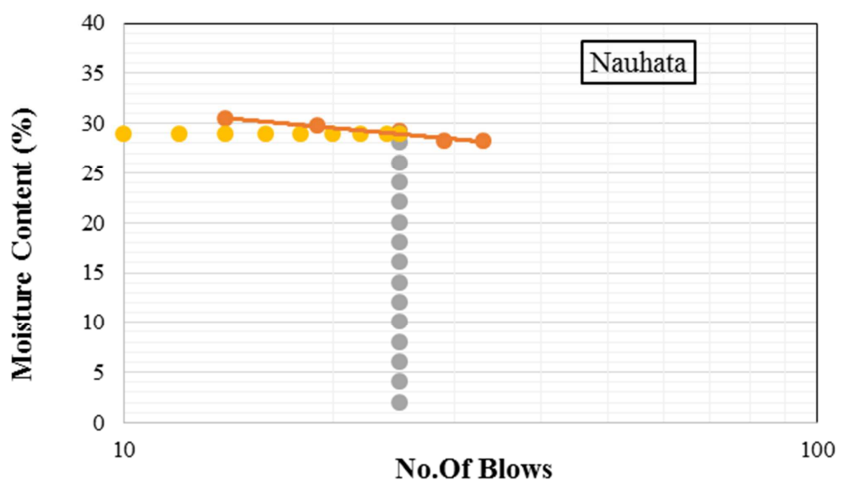

Figure 6. Graph for liquid limit determination by Casagrande Method (Nauhata Soil).

\subsubsection{Plastic Limit (PL)}

The required water percentage at which the soils act like a plastic. It begins to crumble when rolled into threads at $3 \mathrm{~mm}$ diameter. ASTM D-4318 was also considered in the determination of plastic limit. Three samples were tested from each location, and the required moisture content was recorded concerning plastic limit and showed in table 1.

Table 1. Plastic Limits of Godagari, Tanore, and Nauhata.

\begin{tabular}{ll}
\hline Location & Plastic Limit (\%) \\
\hline Godagari & 21.48 \\
Tanore & 17.93 \\
Nauhata & 19.58 \\
\hline
\end{tabular}




\subsubsection{Plasticity Index (PI)}

Plasticity Index is an easy tool to characterise the soil profile which is depending on the LL and PL values. The observed values were given in table 2 . Considering plasticity index chart indicate the soil strata for Godagari and Tanore lie in the medium plastic zone of inorganic in nature but considering Nauhata unveils low plasticity zone of having inorganic clays for the position of below $10 \%$ of PI.

Table 2. Plasticity Index of Godagari, Tanore, and Nauhata.

\begin{tabular}{llll}
\hline Location & LL & PL & PI \\
\hline Godagari & 36.14 & 21.48 & 14.66 \\
Tanore & 30.08 & 17.93 & 12.15 \\
Nauhata & 28.96 & 19.58 & 9.38 \\
\hline
\end{tabular}

\subsection{Fall Cone Test}

British Standard (BS 1377) was applied to perform the fall cone test. The penetration $(\mathrm{mm})$ concerning the moisture content (\%) [Table 3] was plotted on a log-log scale [figures $7,8 \& 9]$ and a regression analysis was carried out to obtain the liquid limit for Godagari, Tanore, and Nauhata. The empirical correlation developed by Feng [22] was used to determine the plastic limit of each location. The regression coefficient was recorded from the spreadsheet, and finally, the plastic limit was established. The following equation was used in the determination of plastic limit:

$$
\mathrm{PL}=\mathrm{C}(2)^{\mathrm{m}}
$$

Where $\mathrm{C}$ and $\mathrm{m}$ is the coefficient to consider the best fit curve as a power equation. The values of $\mathrm{C}$ and $\mathrm{m}$ along the determination of LL and PL is shown as a tabular style in table 4 .

Table 3. Moisture Content \& Penetration for Fall Cone Test.

\begin{tabular}{lll}
\hline Location & Moisture Content $(\%)$ & Penetration $(\mathbf{m m})$ \\
\hline \multirow{3}{*}{ Godagari } & 28.93 & 20 \\
& 35.26 & 120 \\
& 45.7 & 295 \\
Tanore & 30.43 & 35 \\
& 38.69 & 150 \\
& 42.45 & 360 \\
Nauhata & 25.81 & 18 \\
& 33.42 & 90 \\
\hline
\end{tabular}

Table 4. Regression Coefficients and Calculated LL \& PL in FCT.

\begin{tabular}{lllll}
\hline Location & $\mathbf{C}$ & $\mathbf{m}$ & PL & LL \\
\hline Godagari & 17.432 & 0.165 & 19.54 & 29.03 \\
Tanore & 18.312 & 0.1451 & 20.25 & 31.59 \\
Nauhata & 18.185 & 0.1266 & 19.85 & 27.98 \\
\hline
\end{tabular}

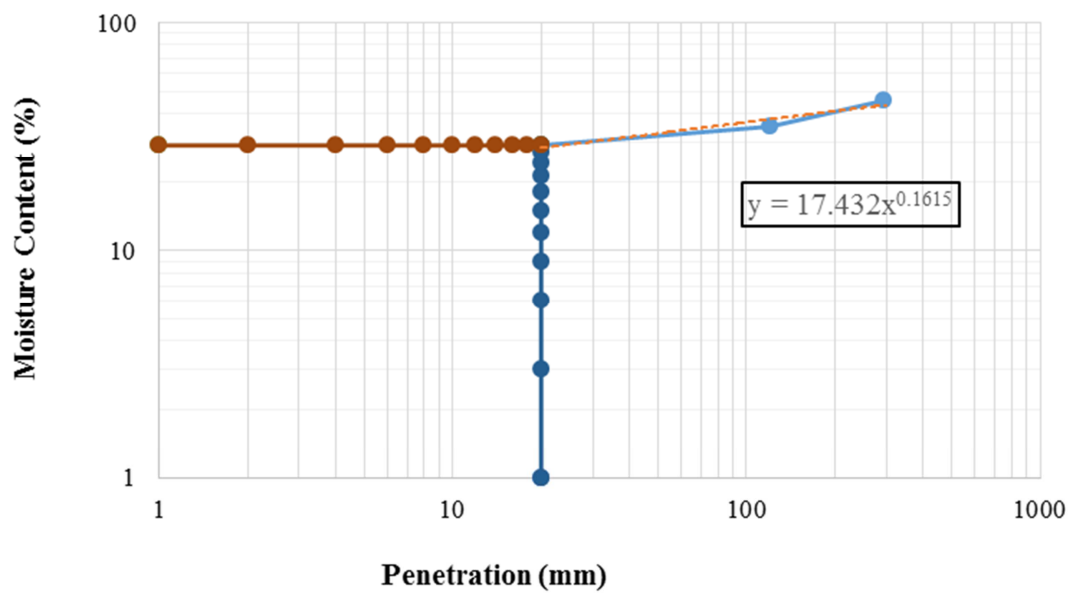

Figure 7. Fall Cone Test results for Godagari Soil.

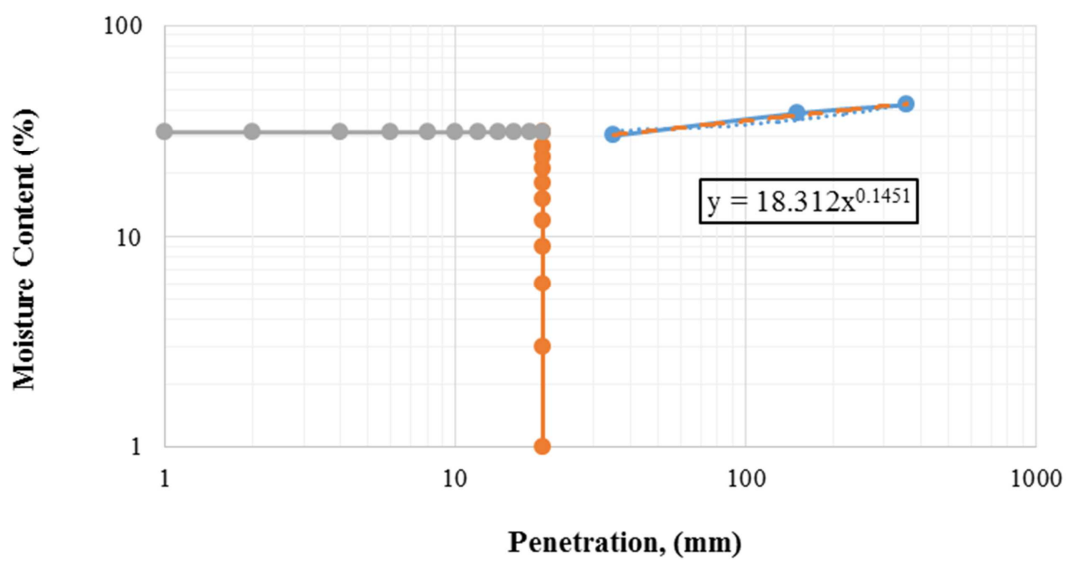

Figure 8. Fall Cone Test results for Tanore Soil. 


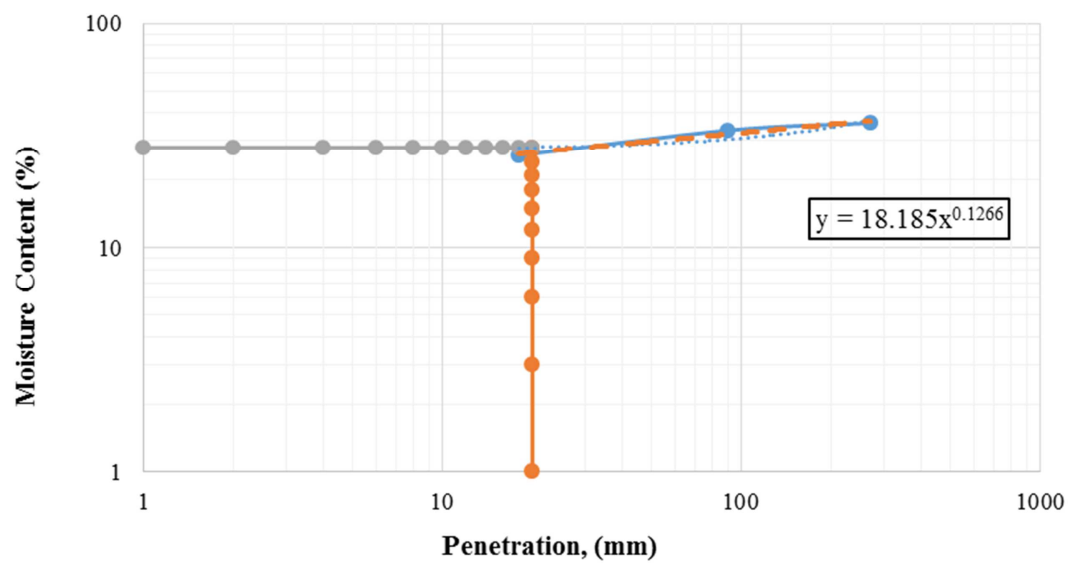

Figure 9. Fall Cone Test results for Nauhata Soil.

\subsection{Determination of Shear Strength}

Table 5. Average Shear Strength obtained in UCS Test.

\begin{tabular}{llll}
\hline Location & Sample No. & $\begin{array}{l}\text { Shear Strength } \\
(\mathbf{k P a})\end{array}$ & $\begin{array}{l}\text { Average Shear } \\
\text { Strength (kPa) }\end{array}$ \\
\hline \multirow{3}{*}{ Godagari } & 1 & 26.5 & \\
& 2 & 32 & 28.5 \\
& 3 & 27.5 & \\
Tanore & 1 & 64 & 59.5 \\
& 2 & 60.5 & \\
Nauhata & 3 & 54 & 53.67 \\
& 1 & 53.5 & \\
\hline
\end{tabular}

Three samples were taken for the Unconfined Compression Strength tests for every location. The result of sample no. 1 of Godagari soil is displayed in figure 10. Following this procedure of plotting, other data were attained, and the average shear strength for UCT test was shown in table 5.

A developed empirical equation has been utilised to evaluate the shear strength of the clayey soil. The used relation is stated herewith:

$$
\mathrm{S}_{\mathrm{u}}=\mathrm{q}_{\mathrm{u}} / 2
$$

Where $S_{u}$ denotes the shear strength whereas $q_{u}$ indicates the unconfined compressive strength. From the line graph, Unconfined compressive strength, $\mathrm{q}_{\mathrm{u}}=53 \mathrm{kPa}$.

Shear strength, $\mathrm{S}_{\mathrm{u}}=\mathrm{q}_{\mathrm{u}} / 2(\mathrm{kPa})$

$\mathrm{S}_{\mathrm{u}}=26.5 \mathrm{kPa}$.

On the other hand, an empirical relation $\left[\mathrm{S}_{\mathrm{u}}=\mathrm{K}^{*} \mathrm{mg} / \mathrm{d}^{2}\right.$ (Hansbo)] was used to calculate the shear strength of soil profiles of selected areas from the FCT method and given in table 6 .

Table 6. Determination of Shear Strength from FCT.

\begin{tabular}{llll}
\hline Location & Penetration depth, $\mathbf{d}(\mathbf{m m})$ & Mass of cone, $\mathbf{m}(\mathbf{k g})$ & Cone factor, $\mathbf{K}$ \\
\hline Godagari & 87.40 & 0.3 & 1.52 \\
Tanore & 69.93 & 0.3 & 1.52 \\
Nauhata & 72.43 & 0.3 & 1.52 \\
\hline
\end{tabular}

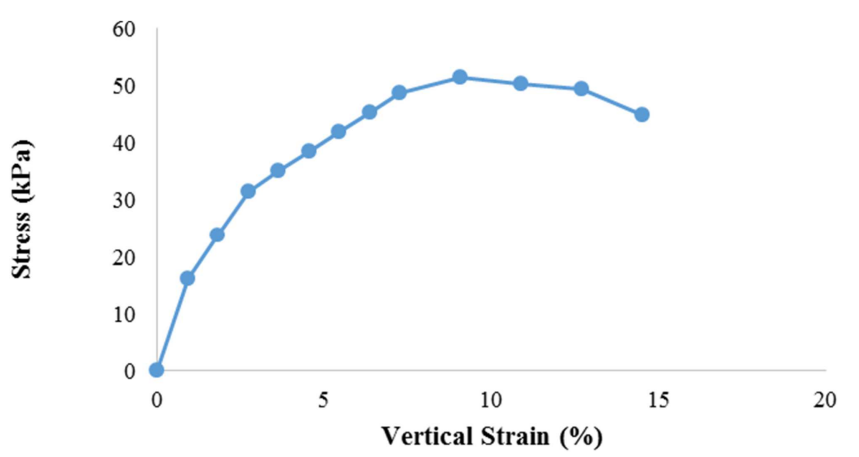

Figure 10. Stress versus strain behaviour of UCS for sample 1 of Godagari soil.

\section{Comparison}

\subsection{Comparison of Consistency Behavior}

Liquid limit and plastic limit values for Godagari, Tanore, and Nauhata soil have differed in case of Fall Cone Test from
Casagrande Method. Comparisons for liquid limit and plastic limit are shown in Table 7 and 8 respectively.

Table 7. Comparison between Casagrande Method \& Fall Cone Test for Liquid Limit.

\begin{tabular}{lll}
\hline Soil & Casagrande Method (\%) & Fall Cone Test (\%) \\
\hline Godagari & 36.14 & 29 \\
Tanore & 30.08 & 27.5 \\
Nauhata & 28.96 & 26 \\
\hline
\end{tabular}

Table 8. Comparison between Casagrande Method \& Fall Cone Test for Plastic Limit.

\begin{tabular}{lll}
\hline Soil & Casagrande Method $(\%)$ & Fall Cone Test $(\%)$ \\
\hline Godagari & 21.48 & 18 \\
Tanore & 17.93 & 20 \\
Nauhata & 19.58 & 17 \\
\hline
\end{tabular}

\subsection{Comparison of Shear Strength}

Shear strength for Godagari, Tanore, and Nauhata soil 
have differed in case of Fall Cone Test from Unconfined Compression Test Comparison of shear strength is noted in Table 9.

Table 9. Comparison between Unconfined Compression Test \& Fall Cone Test for Shear Strength.

\begin{tabular}{lll}
\hline Soil & $\begin{array}{l}\text { Unconfined Compression } \\
\text { Test }(\mathbf{k P a})\end{array}$ & $\begin{array}{l}\text { Fall Cone Test } \\
(\mathbf{k P a})\end{array}$ \\
\hline Godagari & 28.5 & 36.5 \\
Tanore & 59.5 & 57.05 \\
Nauhata & 53.67 & 53.19 \\
\hline
\end{tabular}

\section{Conclusions}

This research was conducted to compare the experimented results of consistency behaviour and shear strength of clayey soils collected from three different locations of Rajshahi District, Bangladesh namely Godagari, Tanore, and Nauhata which were previously noted with clay by literature. The LL for three grounds obtained from FCT results for Godagari, Tanore and Nauhata is $29.03 \%, 31.59 \%$, and $27.98 \%$ whereas that of the soil derived from Casagrande method are $36.14 \%$, $30.08 \%$, and $28.96 \%$ respectively. This is because of failure of determining the accurate number of blows required for coming to the two halves of the soil cake in contact with the bottom of the groove along the distance of about $12 \mathrm{~mm}$ in Casagrande Method. The water required to divert the plastic state to the liquid state is higher for Tanore considering FCT whether Godagari shows more consistency considering Casagrande method. Considering the PL for the soils are respectively $19.54 \%, 20.25 \%$ and $19.85 \%$ measured by FCT but $21.48 \%, 17.93 \%$, and $19.58 \%$ by Casagrande method. The soil of Godagari loses its plastic state when it is mixed with the water per cent of 21.48 in Casagrande, but in FCT method Tanore shows a higher percentage of water requirement which is 20.25 . This is because of ignorance during kneading to the soil by hand until the crack if showed up in case of Casagrande Method. In the fact of shear strength, the UCT results for Godagari, Tanore, and Nauhata soils are $28.5 \mathrm{kPa}, 59.5 \mathrm{kPa}$, and $53.67 \mathrm{kPa}$ respectively, on the contrary, the FCT results are $36.5 \mathrm{kPa}, 57.05 \mathrm{kPa}$, and $53.19 \mathrm{kPa}$. Taking the shear strength into consideration, it was revealed that Tanore gives higher shear strength in both FCT and UCT.

\section{Acknowledgements}

The soil lab of Rajshahi University of Engineering \& Technology has been used to perform the research. The authors would be grateful to the journal review committee to give a fantastic shape of this paper.

\section{Conflict on Interests}

This prepared manuscript is not related to any conflict of interests.

\section{References}

[1] Landris, T. L., and Freeman R. B. (2009). "Dual Weight Fall Cone Method for Simultaneous Liquid and Plastic Limit Determination". Journal of Geotechnical and Geoenvironmental Engineering, ASCE, Vol. 135, No. 1, pp. 158-161, DOI: 10.1061/(ASCE)10900241(2009)135\%3A1(158).

[2] Sivakumar, V., Glynn, D., Cairns, P. and Black, J. P. (2009). "A New Method of Measuring Plastic Limit of Fine Materials". Geotechnique, Vol. 59, No. 10, pp. 813-823, DOI: 10.1680/geot.2009.59.10.813.

[3] Wood, D. M., and Worth, C. P. (1978). "The use of Cone Penetrometer to Determine the Plastic Limit of Soils". Journal of Ground Engineering, Vol. 11, No. 3, p. 37, ISSN: 00174653 .

[4] Wood D. M. (1985), "Some Fall Cone Tests". Geotechnique, Vol. 35, No. 1, pp. 64- 68, DOI: 10.1680/geot.1985.35.1.64.

[5] Feng, T. W. (2004). "Using Small Ring and Fall Cone to Determine the Plastic Limit". Journal of Geotechnical and Geoenvironmental Engineering, ASCE, Vol. 130, No. 6, pp. 630-635, DOI: 10.1061/(ASCE)10900241(2004)130\%3A6(630).

[6] Wasti, Y. and Bezirci, M. H. (1986). "Determination of the Consistency Limits of Soils by the Fall Cone Test". Canadian Geotechnical Journal, Vol. 23, No. 2, pp. 241-246, DOI: 10.1139/t86-033.

[7] Harrison, J. A. (1988). "Using the BS Cone Penetrometer for the Determination of the Plastic Limits of Soils". Geotechnique, Vol. 38, No. 3, pp. 433-438, DOI: 10.1680/geot.1988.38.3.433.

[8] Koumoto, T., and Houlsby, G. T. (2001). "Theory and Practice of the Fall Cone Test ". Geotechnique, Vol. 51, No. 8, pp. 701712, DOI: 10.1680/geot.2001.51.8.701.

[9] Muntohar A. S. and Hashim (2005). "Determination of Plastic Limits of Soils Using Cone Penetrometer: Re-Appraisal". Jurnal Teknik Sipil, Vol. 11, No. 2.

[10] Rashid, A. S. B. A. (2005). "Determination of Plastic Limit of Soil using Modified Cone Penetration Method". M.Sc. Thesis, Univ. of Malaysia.

[11] Prakash, K. and Sridharan, A. (2006). "Critical Appraisal of the Cone Penetration Method of Determining Soil Plasticity". Canadian Geotechnical Journal, Vol. 43, No. 8, pp. 884-888, DOI: $10.1139 / \mathrm{t} 06-043$

[12] Ying, G., and Wang, Q, (2009). "Experimental Research on Fall Cone Test to Determine Liquid Limit and Plastic Limit of Silts". Journal of Rock and Soil Mechanics, Vol. 30, No. 9, pp. 2569-2574.

[13] Christaras, B. (1991). "A comparison of the Casagrande and fall cone penetrometer methods for liquid limit determination in marls from Crete, Greece". Engineering Geology, ELSEVIER, Vol. 31, No. 2, pp. 131-142, DOI: 10.1016/00137952(91)90002-3.

[14] Spagnoli. G. (2012). "Comparison between Casagrande and drop-cone methods to calculate liquid limit for pure clay". Canadian Journal of Soil Science, Vol. 92, No. 6, pp. 859-864, DOI: $10.4141 /$ cjss2012-011. 
[15] Hrubesova, E., Lunackova, B., and Brodzki. O. (2016). "Comparison of Liquid Limit of Soils Resulted from Casagrande Test and Modified Cone Penetrometer Methodology". Procedia Engineering, ELSEVIER, Vol. 142, pp. 364-370, DOI: 10.1016/j.proeng.2016.02.063.

[16] Namdar, A. (2008). "Identification of Mixed Soil Characteristics by Application of Laboratory Tests". Electronic Journal of Geotechnical Engineering, EJGE, Vol. 14 , Bund.

[17] Houlsby, G. T. (1982). "Theoretical Analysis of Fall Cone Tests". Geotechnique, Vol. 32, No. 2, pp. 111-118, DOI: 10.1680/geot.1982.32.2.111.

[18] Sariosseiri, F., and Muhunthan, B. (2008). "Geotechnical Properties of Palouse Loess Modified with cement Kiln Dust and Portland Cement". GeoCongress, ASCE, DOI: 10.1061/40972(311)12.
[19] Lawrence, D. M. (1980). "Some properties associated with Kaolinite soils". M.Sc. Thesis, Cambridge University, UK.

[20] Wasti, Y. (1987). "Liquid and Plastic Limits as Determination from the Fall Cone and the Casagrande Methods". Geotechnical Testing Journal, Vol. 10, No. 1, pp. 26-30, DOI: $10.1520 /$ GTJ10135J.

[21] GEONOR (2010). "Fall Cone Apparatus- New Model Designed by Norwegian Geotechnical Institute NGI". Oslo, Norway.

[22] Feng, T. W. (2000). "Fall Cone Penetration and Water Content Relationship of Clays". Geotechnique, Vol. 50, No. 2, pp. 181187, DOI: 10.1680/geot.2000.50.2.181. 